\title{
Factors Influencing the Adoption of Online Trading: A Study of Individual Investors.
}

\author{
Dr. Apar Singh ${ }^{1}$, Meenakshi Malhotra ${ }^{2}$ \\ ${ }^{I}$ School of Management Studies, Punjabi University Patiala, \\ ${ }^{2}$ Doctoral student School of Management Studies, Punjabi University Patiala
}

\begin{abstract}
This study investigates demographic factors influence on investors' behaviour in adopting online trading and to determine success factors and resistance factors affecting adoption of online trading. We developed a research model which integrates Perceived Usefulness, Perceived Benefits, Perceived Ease of Use, Attitude, and Subjective norms, Perceived Behavioral Control, Perceived Risk, Trust and Intention to adopt online trading. Data were collected with the help of structured questionnaire which was further subjected to chisquare test and factor analysis of respondents in SPSS and SPSS AMOS respectively. Results shows that home ownership, income, trading experience and occupation effect the adoption of online trading but marital status, age, gender, education, type of trade and trading frequency does no effect adoption of online trading. Similarly perceived benefit and perceived risk has no direct impact on adoption of online trading.
\end{abstract}

Keywords: Demographics, TAM, TRA and intention to adopt online trading.

\section{Introduction}

In the era of $21^{\text {st }}$ century technology provide advantages to the individual such as faster transactions, low cost etc. (Insight Xplorer, 2007). Even geographical barriers have been removed (Yap and Lin, 2001). But still these services are not utilized by common man. One of the important areas that were affected by IT sector was stock broking services (Dasgupta, 2002). Though the operations in stock trading were successfully updated by the effect of technology (Shankar, 2002) but the usage of the service is limited.

Previous studies have tried to analyse on the adoption of e commerce applications but little work has been done towards adoption of online trading. This research paper will try to understand the factors which motivates and resist the individuals for the adoption of online trading. Investor's decision is not rational in nature but dependent on various psychological factors (Murgea, 2008). These factors may have positive and negative effect on adoption of behaviour. In addition to this demographic characteristics also affect the adoption of Online trading (Wen lin 2011).

Adoption of online trading is depended on various factors. Literature surveys show that researchers for theoretical support have used various models. In this research paper we have used a combination of TAM and TRA model to understand the user perception towards adoption of online trading. In 1986 Davis put forward a Technology Acceptance Model (TAM), which predicted the factors influencing the decision of an individual in acceptance of new technology. TAM is an extension of Theory of reasoned action (Ajzen 1980). According to TAM, Perceived usefulness and Perceived Ease of Use are two constructs which affects the individuals Attitude and Intention to adopt a technology. As defined by Fred Davis Perceived usefulness (PU) is the degree to which a person believes that using a particular system would enhance his or her job performance and Perceived easeof-use (PEOU) is the degree to which a person believes that using a particular system would be free from effort. According to Theory of reasoned action (TRA) behavioural intention is the immediate motivator for individuals to perform the behaviour. Behavioural intention is further dependent on two factors Attitude and subjective norms. According to Ajzen Attitude toward the behaviour is defined as one's general feelings indicating their favourableness or unfavourableness to the behaviour. Subjective norm is defined as one's perception regarding whether their significant others think the behaviour should be performed or not. In the year 2002 Ajzen added perceived behavioural control as one of the factor affecting behavioural intention. Perceived behavioural control is defined as one's perception of the ease or the difficulty in conducting the concerned behaviour, relating to the existence or absence of necessary resources and opportunities

\section{Literature Review}

Adela et al. (2001) examined the adoption of Online trading in the Hong Kong financial market. Data was collected from 178 respondents. Questionnaire was in two parts. First part collected information regarding demographic variable and second part consisted of decomposed version theory of planned behaviour. The results of the analysis indicate that Perceived Usefulness, Perceived Ease of Use, and Compatibility significantly affect the Attitude towards using the proposed system. This implies that investors will possess positive feelings for using online trading if it can enhance their efficiency and effectiveness of placing orders. 
Teo et al. (2004) examined the attitudes of adopters and non-adopters towards internet stock trading in Singapore. Data were collected using a web-based questionnaire survey. This study examines the demographic profiles and attitude of adopters and non-adopters. It concluded that nearly $80 \%$ of the Internet stock trading respondents preferred using the Internet to trade over conventional means of trading. Internet stock brokerages can encourage clients to trade through them by offering value added services such as free access to premium investment reports (purchased by the company) or free access to current financial news. It could offer security and a premium service guarantee to encourage adoption.

Lee (2009) collected data from 338 respondents through Web based survey in Taiwan. Questionnaire was in two parts. First part collected information regarding respondent's gender, age, education, occupation and experience using online trading. Second part was developed based on the construct of Perceived risk, Perceived benefits, Trust, TAM and TPB. The results showed that Perceived Risk is more important factor than Perceived Benefit. The study further showed that the trust is the critical factors that affect the investor intensions. Therefore system should develop trust building strategies to entice investors into embracing online trading.

Singh et. al. (2010) examined whether investors who adopted Internet stock trading perceived differently from those of non-adopters. The primary data were based on 299 investors (149 adopters and 150 non-adopters). Results indicated that attitude dimensions and demographic variables contributed significantly in classifying investors as adopters or non-adopters in Internet trading. Attitude dimensions, variety of financial products and safety contributed significantly in discriminating between adopters and non-adopters of Internet trading followed by the factor such as 'convenience and transparency'.

Majali (2013) investigated the factors that could predict the customers' attitude towards using internet trading services in Jordon. The sample was taken randomly from telephone directories of 10 selected companies in Amman stock exchange in Jordan. It examined perceived usefulness, perceived ease of use, compatibility, trial-ability, trust and awareness. Results showed that awareness appear to be the most important factor among all the factors.

Singh (2013) examined whether brokers who adopted net stock trading perceived differently from those of non-net based brokers. The primary data based on 196 brokers (92 brokers and 104 non-net based brokers). As regards demographics, young brokers were more adaptable to the latest Internet technology as a medium of providing trading facility in comparison to aged and experienced brokers due to lack of education and awareness about this medium. As far as the attitude dimensions were concerned, 'economic, convenience and transparency' contributed significantly in discriminating between net brokers and non-net brokers.

Parkash et al. (2014) observed the various socio-economic characteristics like income, age, gender, occupation, education and marital status on risk taking behavior of the individual. Using snowball sampling method 200 questionnaires were filled by the individuals of the region Karachi, who make investments and have knowledge about different investment avenues. Results shows that gender has no relationship with risk taking ability but other factors like marital status, higher education and income of individual affects the risk taking capacity of individual.

\section{Research Methodology}

The first objective of the study is to investigate the effect of demographics on the adoption of Online Trading. Ten definite characteristics were analyzed: Age, Gender, Home Ownership, Marital Status, Income, Education, Trading Experience, Trading Frequency, Type of Trader and Occupation. The second objective is to determine the factors affecting the adoption of online trading. Data was collected with the help of structured questionnaire through simple random sampling. The questionnaire was divided into two major parts: demographics and 5-point attitudinal Likert scale $(1=$ strongly disagreed; $5=$ strongly agreed). The scale comprised of 28 statements. The questionnaire was distributed to the investor's directly and through the help of brokers. Out of the 270 questionnaires 195 completely filled questionnaires were received back (72.22\%). For the questionnaire validity reliability analysis was performed using Cronbach's Alpha. The composite alpha for entire scale was as high as 0.949 .

\section{Result}

The Table 1 shows the demographic profile of the respondents. It shows that respondents of this study were mostly less than 35 years of age. Investors with age group of 35- 45 year s don't prefer to use online trading. However, older people who are retired prefer to do online trading. This is a not consistent wit previous study which says that older people don't prefer to trade online (Li et. al. 2002). According to chi-square test the value of $\mathrm{p}$ is less than .05 therefore there is no significant relationship between age and adoption of online trading (Teo et al. 2004). 
Factors Influencing The Adoption of Online Trading: A Study of Individual Investors.

Table 1: Demographic profile of respondents

\begin{tabular}{|c|c|c|c|c|c|c|c|}
\hline Sno. & Demographics & \multicolumn{2}{|l|}{ Online } & \multicolumn{2}{|l|}{ Offline } & Total & Chi- Square \\
\hline \multirow[t]{6}{*}{1} & Age & Count & $\%$ & Count & $\%$ & & $\begin{array}{lll}\mathrm{df} & = & 4\end{array}$ \\
\hline & less than 25 years & 41 & 63 & 24 & 37 & 65 & \multirow{5}{*}{ 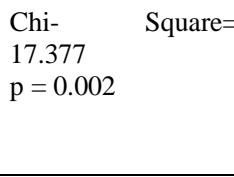 } \\
\hline & $25-35$ Years & 40 & 51 & 38 & 49 & 78 & \\
\hline & $35-45$ Years & 6 & 22 & 21 & 78 & 27 & \\
\hline & 45-55 Years & 9 & 82 & 2 & 18 & 11 & \\
\hline & 55 Years and above & 9 & 64 & 5 & 36 & 14 & \\
\hline \multirow[t]{4}{*}{2} & Marital status & & & & & & \multirow{4}{*}{$\begin{array}{l}\text { df } \quad=\quad 2 \\
\text { Chi- Square }=7.893 \\
p=0.019\end{array}$} \\
\hline & Married & 45 & 50 & 45 & 50 & 90 & \\
\hline & Single & 60 & 60 & 40 & 40 & 100 & \\
\hline & Divorced & 0 & 0 & 5 & 100 & 5 & \\
\hline \multirow[t]{3}{*}{3} & Home Ownership & & & & & & \multirow{3}{*}{$\begin{array}{ll}\mathrm{df} \quad= & 1 \\
\text { Chi- Square } & 0.357 \\
\mathrm{p}=0.550 & \end{array}$} \\
\hline & No & 57 & 56 & 45 & 44 & 102 & \\
\hline & Yes & 48 & 52 & 45 & 48 & 93 & \\
\hline \multirow[t]{3}{*}{4} & Gender & & & & & & \multirow{3}{*}{ 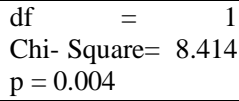 } \\
\hline & Male & 83 & 61 & 54 & 39 & 137 & \\
\hline & Female & 22 & 38 & 36 & 62 & 58 & \\
\hline \multirow[t]{6}{*}{5} & Income & & & & & & \multirow{6}{*}{$\begin{array}{ll}\text { df } \quad= & 4 \\
\text { Chi- Square } & 4.648 \\
\mathrm{p}=0.325\end{array}$} \\
\hline & Less than 25000 & 47 & 52 & 44 & 48 & 91 & \\
\hline & $25000-50000$ & 26 & 46 & 30 & 54 & 56 & \\
\hline & $50000-75000$ & 19 & 68 & 9 & 32 & 28 & \\
\hline & $75000-100000$ & 6 & 67 & 3 & 33 & 9 & \\
\hline & 100000 and above & 7 & 64 & 4 & 36 & 11 & \\
\hline \multirow[t]{6}{*}{6} & Education & & & & & & \multirow{6}{*}{$\begin{array}{lr}\text { df } & 4 \\
\text { Chi- } & \text { Square }= \\
12.658 & \mathrm{p}= \\
0.013 & \end{array}$} \\
\hline & High School & 11 & 46 & 13 & 54 & 24 & \\
\hline & Graduation & 32 & 46 & 37 & 54 & 69 & \\
\hline & Post graduation/ Professional & 39 & 54 & 33 & 46 & 72 & \\
\hline & Finance Professional & 20 & 87 & 3 & 13 & 23 & \\
\hline & $\mathrm{Ph} \mathrm{D}$ & 3 & 43 & 4 & 57 & 7 & \\
\hline \multirow[t]{7}{*}{7} & Trading Experience & & & & & & \multirow{7}{*}{$\begin{array}{lr}\text { df } & = \\
\text { Chi- } & \text { Square }= \\
10.077 & \mathrm{p}= \\
0.073 & \end{array}$} \\
\hline & Less than 1 Year & 54 & 57 & 40 & 43 & 94 & \\
\hline & $1-5$ Year & 31 & 47 & 35 & 53 & 66 & \\
\hline & 6-10 Year & 11 & 48 & 12 & 52 & 23 & \\
\hline & 11-15 Year & 4 & 80 & 1 & 20 & 5 & \\
\hline & 16-20 Year & 5 & 100 & 0 & 0 & 5 & \\
\hline & More than 20 Year & 0 & 0 & 2 & 100 & 2 & \\
\hline \multirow[t]{8}{*}{8} & Trading Frequency & & & & & & $=6$ \\
\hline & Over every 6 month or more & 16 & 36 & 29 & 64 & 45 & Square $=$ \\
\hline & over every 3 month & 9 & 35 & 17 & 65 & 26 & 30.950 \\
\hline & Once a month & 19 & 46 & 22 & 54 & 41 & 0.000 \\
\hline & Once every two week & 5 & 42 & 7 & 58 & 12 & \\
\hline & Once a week & 10 & 77 & 3 & 23 & 13 & \\
\hline & 2-3 times a week & 10 & 67 & 5 & 33 & 15 & \\
\hline & Almost daily & 34 & 85 & 6 & 15 & 40 & \\
\hline 9 & Type of Trade & & & & & & $=\quad 2$ \\
\hline & Intraday Trader & 37 & 82 & 8 & 18 & 45 & Square $=$ \\
\hline & Short Term & 32 & 43 & 42 & 57 & 74 & 18.150 \\
\hline & Long Term & 36 & 51 & 35 & 49 & 71 & 0.000 \\
\hline 10 & Occupation & & & & & & \\
\hline & Salaried Employee & 47 & 53 & 42 & 47 & 89 & Chi- Square $=2.599$ \\
\hline & Businessman/ Professional & 11 & 42 & 15 & 58 & 26 & $\mathrm{p}=0.458$ \\
\hline & Retired & 9 & 64 & 5 & 36 & 14 & \\
\hline & Students/Others & 38 & 58 & 27 & 42 & 65 & \\
\hline
\end{tabular}

The statistical results shows that $60 \%$ of the investors who are single prefer to trade online but investors who are divorced don't prefer to trade online. However, the value of $\mathrm{p}$ in chi-square test is less than .05 therefore there is no significant relationship between marital status and adoption of online trading.

The above table shows that home ownership does not affect the adoption of online trading. However the result of Chi-Square shows that there is significant relationship between home ownership and adoption of Online trading.

Statistical analysis shows that male prefer to trade online in comparison to females $(62 \%$ of male and $38 \%$ of female trade online). This is consistent with the previous researches were maximum of the internet adopter were female (Teo et al. 2002). But the percentage of internet usage is increasing in case of females. Results of Chi- Square test show that there is no significant relationship between gender and adoption of Online Trading. 
There is significant relationship between income and adoption of online trading. This is similar to the previous studies (Teo et al. 2002). Investors of income greater than 50000 Rs. per month predominantly prefer to trade online.

The above table shows that investors who have knowledge of finance or who do intraday trading prefer to trade online. However other education areas do not affect the adoption of online trading. The result is consistent with the result of chi square which says that there is no significant relationship between education or type of trader on adoption of online trading.

A statistical results show that as trading experience and trading frequency is increasing, investors prefer to trade online. However the value of chi square shows that there is no significant effect of trading experience and trading frequency. There is significant relationship between occupation and adoption of online trading. Inventors who are retired or students prefer to trade online.

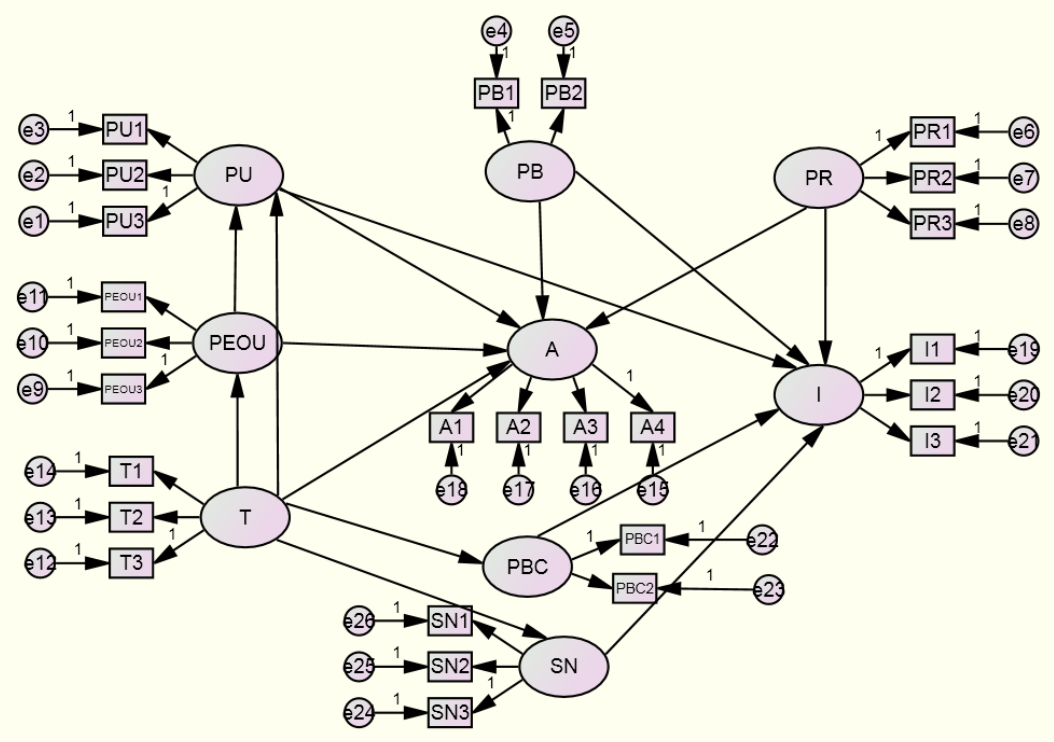

Fig1: Research Model

$\mathrm{PU}=$ Perceived usefulness, $\mathrm{PEOU}=$ Perceived ease of use, $\mathrm{PR}=$ Perceived risk, $\mathrm{SN}=$ Subjective norms, $\mathrm{PBC}=$ Perceived behavioural controls, $\mathrm{PB}=$ Perceived Benefits, $\mathrm{T}=$ Trust, $\mathrm{A}=$ Attitude, and $\mathrm{I}=$ Intention

The 28 significant items of questionnaire was then subjected to exploratory factor analysis using Maximum likelihood coupled with promax rotation. Results put forward 9 components for the variables. For further study Structure equation modelling (SEM) was used to eliminate and test how latent variable and there dimensions are related to each other.

The model has Chi- Square value of 305.289 with 246 degree of freedom $(p=0.006)$ this indicates lack of model fit. But chi-square is sensitive to sample size. Therefore ratio of chi-square to degree of freedom was used to check the fitness of model. The value of the ratio came out to be 1.241, which falls within the suggested value of 3 and below. In addition table 3 shows the fitness criteria of the research model.

Table 2: Summary of fitness criteria

\begin{tabular}{|l|l|l|}
\hline S no. & Fitness Criteria & Result \\
\hline 1 & GFI & .900 \\
\hline 2 & IFI & .987 \\
\hline 3 & CFI & .987 \\
\hline 4 & RMSEA & .035 \\
\hline 5 & CMIN & 1.241 \\
\hline
\end{tabular}

Table 3: Summary Factor loading and Cronbach's alpha value

\begin{tabular}{|l|l|l|l|}
\hline Construct & Item & Factor Loading & Cronbach's alpha \\
\hline \multirow{3}{*}{ Perceived Usefulness } & PU1 & .689 & 0.868 \\
\cline { 2 - 3 } & PU2 & .677 & \\
\cline { 2 - 3 } & PU3 & .700 & \\
\hline
\end{tabular}


Factors Influencing The Adoption of Online Trading: A Study of Individual Investors.

\begin{tabular}{|c|c|c|c|}
\hline & PU4 & .733 & \\
\hline \multirow[t]{4}{*}{ Perceived Ease of Use } & PEOU1 & .574 & \multirow[t]{4}{*}{0.867} \\
\hline & PEOU2 & .680 & \\
\hline & PEOU3 & .571 & \\
\hline & PEOU4 & .530 & \\
\hline \multirow[t]{4}{*}{ Attitude } & A1 & .675 & \multirow[t]{4}{*}{0.916} \\
\hline & $\mathrm{A} 2$ & .607 & \\
\hline & A3 & .608 & \\
\hline & A4 & .568 & \\
\hline \multirow[t]{3}{*}{ Subjective Norms } & SN1 & .765 & \multirow[t]{3}{*}{0.879} \\
\hline & SN2 & .633 & \\
\hline & SN3 & .471 & \\
\hline \multirow{2}{*}{$\begin{array}{l}\text { Perceived Behavioral } \\
\text { Control }\end{array}$} & PBC1 & .636 & \multirow[t]{2}{*}{0.837} \\
\hline & $\mathrm{PBC} 2$ & .593 & \\
\hline \multirow[t]{3}{*}{ Intention } & I1 & .787 & \multirow[t]{3}{*}{0.892} \\
\hline & $\mathrm{I} 2$ & .704 & \\
\hline & $\mathrm{I} 3$ & .574 & \\
\hline \multirow[t]{3}{*}{ Trust } & $\mathrm{T} 1$ & .831 & \multirow[t]{3}{*}{0.793} \\
\hline & $\mathrm{T} 2$ & .733 & \\
\hline & T3 & .521 & \\
\hline \multirow[t]{2}{*}{ Perceived Benefits } & PB1 & .777 & \multirow[t]{2}{*}{0.727} \\
\hline & PB2 & .729 & \\
\hline \multirow[t]{3}{*}{ Perceived Risk } & PR1 & .816 & \multirow[t]{3}{*}{0.864} \\
\hline & PR2 & .947 & \\
\hline & PR3 & .947 & \\
\hline
\end{tabular}

Generally, fit statistics greater than or equal to 0.9 for GFI, 1FI, CFI indicates good model fit (Bagozzi et al., 1991). Furthermore, RMSEA value is less than 0.9 and CMIN value less than 3 . All these values indicate that our model fit was accepted. Chronbach's alpha score in Table 3 indicates strong internal reliability.

Table 4: Summary of hypothesis tests.

\begin{tabular}{|l|l|l|l|}
\hline Hypothesis & Estimate & Sign & Supported \\
\hline PEOU- T & 0.309 & Positive & Yes \\
\hline PEOU-PU & 0.279 & Positive & Yes \\
\hline T-PU & 1.12 & Positive & Yes \\
\hline T-PB & 1.12 & Positive & Yes \\
\hline PU-A & 0.382 & Positive & Yes \\
\hline PEOU-A & 0.14 & Positive & No \\
\hline T-A & 1.163 & Positive & Yes \\
\hline T-PBC & 2.363 & Positive & Yes \\
\hline T-SN & 2.348 & Positive & Yes \\
\hline PR-A & -0.006 & Negative & No \\
\hline PB-A & 0.018 & Positive & No \\
\hline PU-I & 0.295 & Positive & Yes \\
\hline PBC-I & -0.361 & Negative & No \\
\hline SN-I & 0.585 & Positive & Yes \\
\hline A-I & 0.417 & Positive & Yes \\
\hline PR-I & 0.003 & Positive & No \\
\hline PB-I & 0.03 & Positive & No \\
\hline
\end{tabular}

Note: $\mathrm{PU}=$ Perceived usefulness, $\mathrm{PEOU}=$ Perceived ease of use, $\mathrm{PR}=$ Perceived risk, $\mathrm{SN}=$ Subjective norms, $\mathrm{PBC}=$ Perceived behavioural controls, $\mathrm{PB}=$ Perceived Benefits, $\mathrm{T}=$ Trust, $\mathrm{A}=$ Attitude, and $\mathrm{I}=$ Intention

\section{Discussion And Future Implications}

Results shows that Perceived Usefulness, Perceived ease of Use, Perceived Behavioural Control, Subjective Norms, Perceived Risk, Perceived Benefits, Trust and Attitude are the factors that affect the adoption of Online Trading. Intention is adversely affected by Perceived Behavioural Control $(\beta=-0.361, \mathrm{P}<.05)$. Notably, Trust has a strong indirect effect and Attitude has a strong direct effect on Intention. On the other hand, Perceived Behavioural Control has a negative effect on intention to adopt online trading. The results are contrary to Lee (2009) where perceived risk was a key indicator and having negative effect on Intention. Moreover, only Perceived Usefulness $(\beta=0.382)$ affects Attitude. The effect of Perceived Usefulness is stronger on Attitude than Perceived ease of Use which is consistent with previous studies.

The results are consistent with Lee (2009), which suggest that Trust is an important antecedent of three determinants of Intention i.e. Attitude $(\beta=1.163)$, Perceived usefulness $(\beta=0.382)$, Perceived Benefits $(\beta=1.12)$ in TAM model. Statistics also shows that Trust has a stronger impact on Attitude than Attitude has on Intention. Lastly, Perceived Risk and Perceived Benefits don't directly affect Intention to adopt Online trading. 
Results show building trust is important in comparison to perceived risk. Strategies should be made to build up the trust of investors .Investors should have confidence that the other party will fulfil the commitment that the other party has provided. In other words, e-vendors will be ethical and guarantee for investors online transactions. The acceptance of technology is based on various factors.

\section{References}

[1] A. Lau, J. Yen, and P.Y.K Chau, P.Y.K. 'Adoption of On-line trading in the Hong Kong financial market' ,Journal of Electronic Commerce Research, Vol. 2 ( 2),2001,58-65.

[2] S.H. Thompson, T. Margaret, and S.N. Peck, 'Adopters and non-adopters of internet stock trading in Singapore', Behavior \& Information Technology, Vol 23(May-June), 2004, 211-223.

[3] A.F. Ahmed, and A.S. Jamal, 'Social Cultural factors influencing Consumer Adoption of Online transaction' Management of eBusiness, 11-13 July 2007.

[4] N.O Ndubisi, 'Customers' perceptions and intention to adopt Internet banking: the moderation effect of computer self-efficacy', $A I$ \& Society, Vol. 21, 2007, pp $315-327$.

[5] M.C. Lee, 'Predicting and explaining the adoption of online trading: An empirical study in Taiwan', Decision Support System, Vol. 47, 2009,133-142.

[6] T. Ramayah, K. Rouibah, M. Gopi, and G. Rangel, 'A decomposed theory of reasoned action to explain intention to use Internet stock trading among Malaysian investors', Computers in Human Behavior, Vol. 25, 2009, 1222-1230.

[7] A. Singh, H.S. Sandhu, and S.C. Kundu, 'Investors' Adoption of Internet Stock Trading: A Study', Journal of Internet Banking and Commerce, Vol. 15(April),2010, 1-21.

[8] A. Singh, 'Brokers' Adoption of Net Stock Trading: A Study', American International Journal of Research in Humanities, Arts and Social Sciences, Vol. 4(1), 2013, 14-24.

[9] R. Parkash, M. Awais, and U.A. Warraich, 'Do Socio-Economic factors really Influence risk taking Behavior of individual Investors?' Research Journal of Management Sciences, Vol. 3(6), 2014, 10-13. 